\title{
Government Responsiveness in Developing Countries
}

\author{
Guy Grossman* Tara Slough
}

June 18, 2021

Prepared for the Annual Review of Political Science.

\begin{abstract}
When and how do governments deliver public good and service outputs in response to citizen preferences? We review a large current literature on government responsiveness, with a focus on public good and service delivery in developing countries. We identify three common types of actors present in these accounts: politicians, bureaucrats, and citizens. Much of this literature examines only interactions between dyads of these actors. Specifically, the study of electoral accountability and constituency service emphasizes relationships between citizens (or voters) and politicians. Studies of bureaucratic incentives and political oversight of bureaucrats emphasize interactions between politicians and bureaucrats. Finally, studies of bureaucratic embeddedness and citizen oversight of bureaucrats elaborate interactions between bureaucrats and citizens. We argue that an emerging literature that considers interactions between all three types of actors provides rich theoretical and empirical terrain for developing our understanding of responsiveness and accountability in low- and middle-income countries and beyond.
\end{abstract}

\footnotetext{
*Professor, University of Pennsylvania, ggros a sas . upenn . edu.

${ }^{\dagger}$ Assistant Professor, New York University, tara. s lough @ nyu . edu.

\#We thank Carolina Torreblanca for expert research assistance. For excellent comments, we thank Miriam Golden, Saad Gulzar, Eddy Malesky, Franklin Oduro, Dan Posner, Pia Raffer, Nico Ravanilla, Renard Sexton, Jake Shapiro, and Linda Stern.
} 
When do governments deliver outputs that are responsive to citizen preferences? This question motivates a large body of literature in many contexts spanning different regime types, levels of development, and a wide array of political institutions. In this review, we focus on recent developments in the study of government responsiveness in low- and middle-income countries. While our empirical focus is circumscribed by national levels of economic development, many of the strategic interactions we highlight are relevant beyond these contexts.

Following Manin, Przeworski, and Stokes (1999: p. 9), we characterize a government as responsive if it "adopts policies that are signaled as preferred by citizens." Consistent with this definition, we examine the conditions under which citizen preferences - as signaled by polls, individual or collective action—are reflected in policymaking. Beyond policymaking, however, we stress the importance of policy implementation in the study of government responsiveness. Particularly in settings with more limited bureaucratic or state capacity, how policies get implemented can impact a government's ability or incentives to respond to citizen preferences.

Studies of government responsiveness focus on three classes of actors - that map into the longroute of accountability framework (World Bank, 2003). First, politicians make policies and allocate budgets to shape government outputs. Second, citizens are viewed as the primary recipients of these outputs, generally public goods or services. In contexts with regular elections, citizens are also voters who collectively select politicians, thereby shaping politicians' behavior. Third, bureaucrats are individuals (supervised by, and at at times hired by, politicians) to produce public goods and services. Some ("street level") bureaucrats also interact directly with citizens.

We focus on the processes and interactions through which government actors (politicians or bureaucrats) are more likely to create or implement policies congruent with citizen preferences. A necessary preliminary question is therefore "what policies do citizens prefer?" We do not thoroughly review the literature on public opinion that seeks to measure citizen preferences. However, much of the literature we describe assumes citizen preferences for public (or club) goods and services, spanning (among others) healthcare, education, security, roads, water, sanitation, electricity, and social services. 
There are several reasons that these valence preferences are salient in low- and middle-income countries. First, when parties do not differentiate themselves programmatically and politics is therefore comparatively less ideology-oriented, the distribution of public goods and services across space and groups is more important to citizens (Bleck and Van de Walle, 2013). Second, when government provision of services is more circumscribed, as is the case in many developing countries, citizens may prioritize improving basic service provision (such as access to clean water) to a greater extent.

Like much of the literature that we review, we assume a preference for better (or more) public goods and services. To support this assumption, we compile survey data from Afrobarometer, Arabarometer, Asiabarometer, and LAPOP's Americasbarometer on citizen preferences. Since citizens have little reason to prefer "worse" or fewer services, we focus on the salience of these preferences. To do so, we categorize (generally) open-ended responses to citizens' "most important issue." For each respondent, we code a binary variable taking the value 1 if the citizen mentions a public service or public good and 0 otherwise. We are interested in the proportion of citizens that name one of these goods or services as their most important issue(s). Figure 1 depicts the distribution of this variable across sampling units in each country in our sample. Note that the regional surveys ask for different numbers of priorities, ranging from one to three. This graph uses all stated priorities. As such, the measures vary across regions (as reflected in the facet titles).

Figure 1 shows that, particularly in Africa, Latin America, the Caribbean, and the Middle East, these issues are cited by sizable shares - in some cases even a majority - of the population in many countries. These rates are lower in East Asia. There is heterogeneity in preferences within and across countries, as reflected by the density plots for each country. Notably, in many countries, substantial numbers of respondents also reported manifestations of "bad governance" (i.e., corruption, or concerns about democratic institutions) as their top issue. In the average lowor middle-income country in our sample, $33 \%$ of respondents cite public goods/services as their single most important issue while $16 \%$ cite poor governance. In theory, "bad governance," such as corruption, adversely affect public service delivery outputs (Beekman, Bulte, and Nillesen, 2014). 


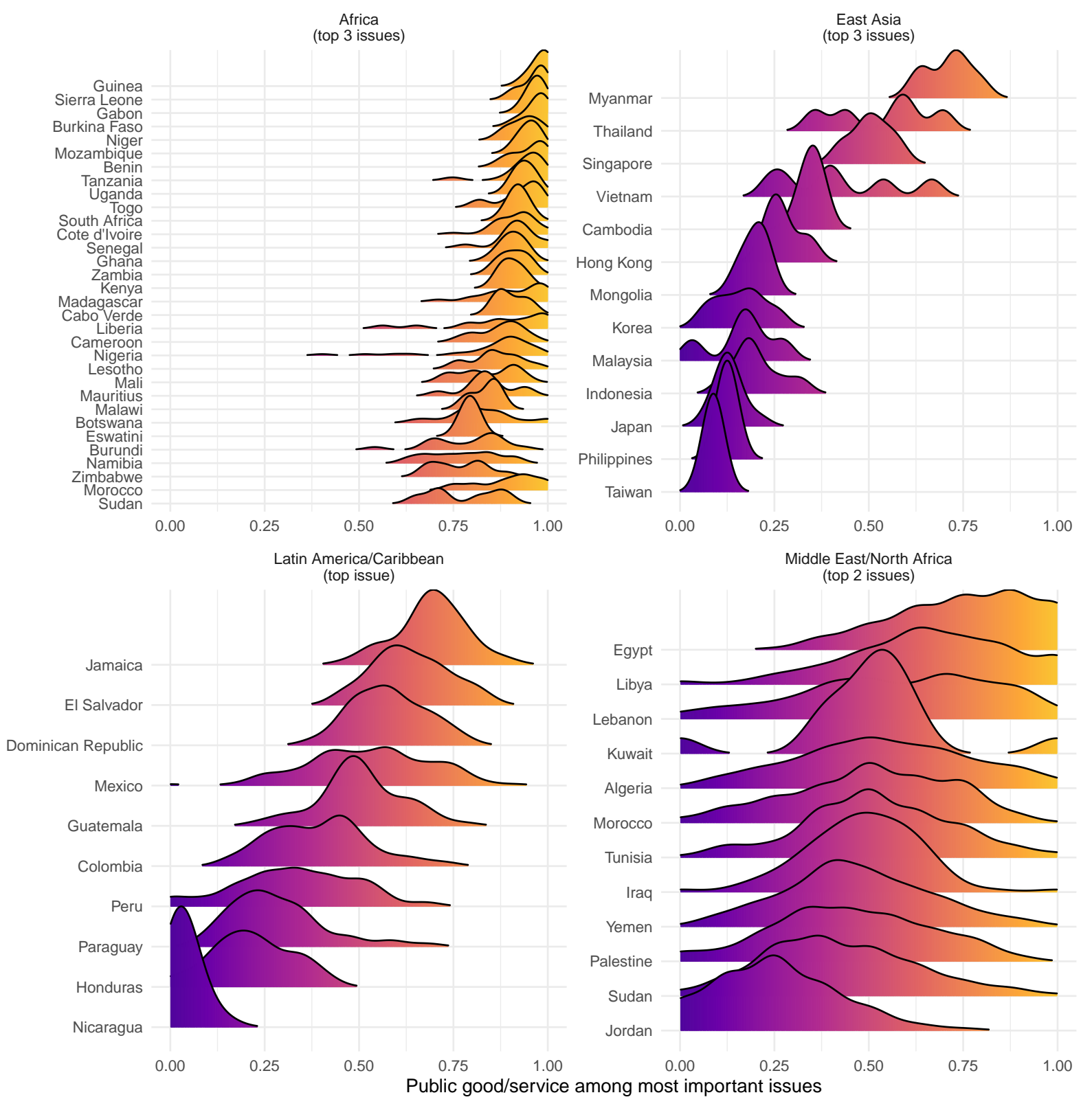

Figure 1: The salience of public goods and services as respondents' top issue. For each country, the density plot depicts variation in the proportion of citizens citing public goods/services across administrative units (i.e., municipalities or regions). Note that Afrobarometer and East Asia Barometer elicit three issues, Arab Barometer elicits two issues, and LAPOP/Americas Barometer elicits one issue in select countries. 
In Figure 2, we show that the rate at which public goods and services are cited as the most important issue decreases in national GDP per capita. Here the outcome refers to only the "most important" issue to main comparability across regional surveys. While our sample is largely circumscribed to low- and middle-income countries given the datasets that we use, Figures 1-2 provide at least suggestive evidence that a study of responsiveness around public goods and services is well-suited to the developing contexts that we emphasize.

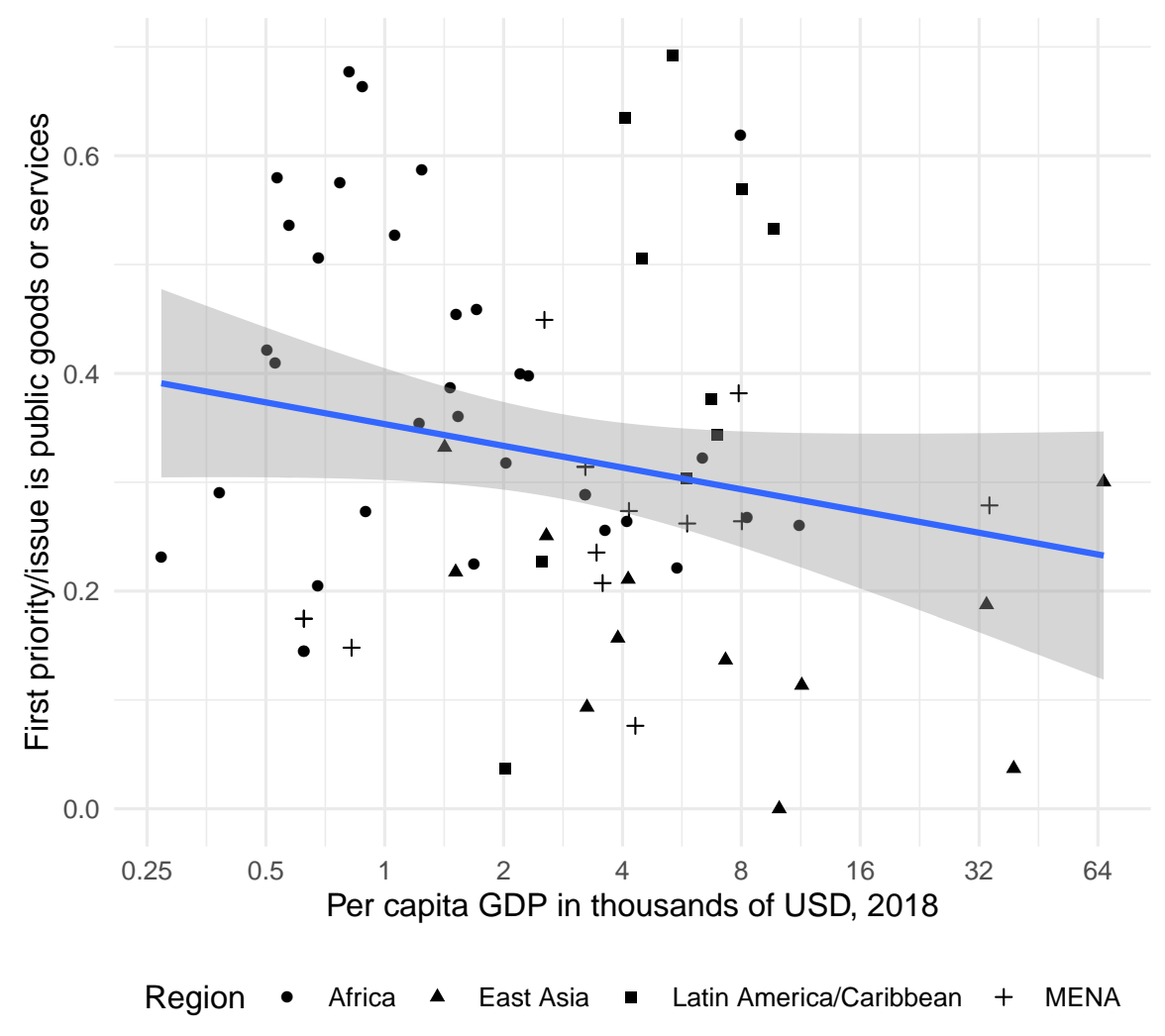

Figure 2: The figure plots per-capita GDP (on a log scale) against the share of citizens citing public goods/services as the most important issue that government should address, showing a negative correlation between the two measures.

We organize our discussion of responsiveness in terms of common strategic interactions between actors. Definitional accounts of responsiveness focus on the government and citizens. Again, building on the highly influential framework of a long- and short-route of accountability (Kosack and Fung, 2014), within the realm of service implementation, we find it useful to disaggregate the "government" into two types of actors: politicians and bureaucrats. In our dis- 
cussions of bureaucrats, we focus most intently on the low- and mid-level bureaucrats tasked with implementing - but not making - policy. ${ }^{1}$ These actors includes both service administrators and frontline service providers, often called street-level bureaucrats (Lipsky, 1980). As such, we examine various interactions between politicians, bureaucrats, and citizens.

With few exceptions, existing works study subsets of these actors: the dyadic relationship between politicians and citizens (voters); politicians and bureaucrats; and bureaucrats and citizens. We therefore organize our review of the existing literature around these three "dyads" of actors. While existing work has important insights, described below, our main argument is that consideration of all three actors within a single framework is generally needed for improving theory but also for reconciling many conflicting findings. As such, a three-actor framework provides a fertile future research agenda, with substantial room for theoretical and empirical development. We demonstrate the utility of this approach with a discussion of recent works that integrate all three actors, including the challenges that this charge introduces.

As for the scope of this review, we abstract from some bodies of work that broadly relate to responsiveness. Specifically, we do not discuss issues of representation in depth; for example, the evolving work on the relationship between descriptive and substantive representation (Wängnerud, 2009). Similarly, we do not review some aspects of distributive politics-for example, whether politicians allocate goods to their core constituents or whether they target swing voters, as well as the logic of their engagement with clientelistic exchange. Indeed, the electoral returns to politicians from different distributive strategies is thoroughly covered in two recent reviews (Golden and Min, 2013; Hicken and Nathan, 2020). Finally, government performance can increase if higher quality citizens choose to run for office in the first place. We do not, however, discuss the growing literature on candidate selection since it was reviewed recently by Gulzar (2021).

In the following sections, we highlight key arguments and findings about each of the three dyads of actors before concluding with our suggestions for further research.

\footnotetext{
${ }^{1}$ Much of the bureaucratic politics literature focused on the US focuses on policymaking bureaucrats, who generally include the top echelons of bureaucrats (see Galimard and Patty (2012) for a review).
} 


\section{Dyad \#1: Politicians and Citizens}

When do politicians pursue policies or allocate resources in the interest of their constituents? How do citizens remedy gaps in state service provision within interactions with politicians? We review recent work on electoral accountability and constituency service, both in democracies and (where applicable) in autocracies.

\subsection{Electoral Accountability}

In developing countries, observation of curtailed public goods provision alongside corruption or malfeasance by politicians motivates many studies of electoral accountability. While the responsiveness of policies to the preferences of the electorate is analytically distinct from whether citizens can select or sanction politicians (Ashworth, 2012), accountability pressures are thought to promote more responsive policymaking (Ofosu, 2019). The focus on electoral accountability raises an important question: assuming that elections are relatively free and fair, under what conditions can voters use periodic elections to induce politicians to advance their (voters') interests?

According to seminal accountability models, elections provide voters the opportunity to select better politicians or sanction politician malfeasance (Fearon, 1999). The literature generally assumes that for (positive) selection or sanctioning of politicians, (a) voters must observe some credible signal of politician performance and (b) update their beliefs rationally (following Bayes' rule) on the basis of this information, and (c) that viable challengers exist, allowing voters to credibly threaten to withdraw their support when incumbents perform below voters' reelection threshold.

Using a principal-agent framework, much of the recent literature on electoral accountability focuses on the problem of imperfect (or asymmetric) information, given the clear theoretical prediction on incumbents' and voters' behavior. When voters lack information on politicians' quality and candidates are unable to credibly commit to enhance citizens' welfare, voters may rationally rely on heuristics, such as candidates' ethnic markers or vote buying efforts, to inform their choice (Posner, 2005). A key goal of studies of the information-accountability nexus is to test whether citizens 
use newly acquired incumbent performance information to inform their vote choice. ${ }^{2}$

Since the extent to which the electorate is informed could be a function of factors that also affect politicians' behavior, a growing body of work has focused on identifying exogenous variation in the information environment (e.g., Larreguy, Marshall, and Snyder, 2020), as well as on the effects of exogenously informing voters about politician performance (i.e., corruption, inputs, truancy, or policy outcomes) in advance of elections on vote choice (e.g., Dunning et al., 2019).

A seminal paper by Ferraz and Finan (2008) leverages the randomized timing of federal audits of Brazilian municipal governments to see whether voters punish mayoral malfeasance at the polls. They find that, relative to municipalities audited after the 2004 election, incumbent re-election prospects of mayors audited before the elections decrease in the level of corruption detected. This effect was stronger in municipalities with community radio stations, the media through which audit results were most likely disseminated. Focusing on service delivery outcomes rather than malfeasance, Goyal (2019), by contrast, does not find that Indian citizens voted for on the basis of rural roads improvements, even when they had access to rich incumbent performance information.

Motivated by mixed findings from natural experiments, a number of recent field experiments endeavor to study the effects of information revelation before elections on vote choice. Here too, the evidence is mixed. On one hand, Chong et al. (2015) finds that exposing Mexican voters to corruption information - culled from independent audit reports—reduced the vote share of the incumbent party. Similarly Banerjee et al. (2020) distributed newspapers containing report cards on politicians in Indian slums just prior to elections. The authors find that greater transparency resulted in gains for better performing and relatively more qualified incumbents.

On the other hand, a pre-registered meta-analysis from six coordinated field experiments in Benin, Burkina Faso, Brazil, Mexico, and Uganda, recover little evidence that "good news" or "bad news" about incumbents' (relative) performance substantially moved survey-reported turnout or votes (Dunning et al., 2019). In these studies, "good news" and "bad news" are measured

\footnotetext{
${ }^{2}$ Imperfect information is not the only barrier to electoral accountability. See Hicken and Nathan (2020) for a recent review of the role of clientelism in distorting performance-based voting and Rozenas (2016) on electoral manipulations employed by incumbents to subvert voters' sanctioning.
} 
on different dimensions (i.e., corruption or legislator attendance) in different places. A further meta-analysis of natural and field experiments similarly finds no effect of corruption revelation on incumbent vote share (Incerti, 2020).

Several explanations have been put forth to organize mixed findings on information and voter selection of politicians. Some explanations question citizens' ability to update based on political information, others question the idea that voters are information seekers, and there are also those who focus instead on identifying the type of messages and messengers that are most likely to affect voter behavior.

As mentioned, it may be that a key barrier to voter use of information to select politicians is limited voter rationality. Here, survey experiments may be most informative. In general, survey experiments on information and accountability typically provide respondents (analogous to voters) with information about a politician's actions or their outcomes. Respondents then evaluate the politician. In these experiments, voters tend to update substantially in the direction of the evidence, consistent with rational processing of the information (Incerti, 2020; Bhandari, Larreguy, and Marshall, 2021). To the extent that survey experiments capture voter beliefs (as opposed to actions), findings are consistent with rational voter responses to information.

Several studies seek to identify the type of incumbent information that is most relevant (salient) to voters. For example, using an experimental research design, Bhandari, Larreguy, and Marshall (2021) find that Senegalese voters are more likely to use benchmarked information about local development outcomes than about legislative efforts within parliament. Adida et al. (2020) demonstrate that the saliency of politician performance information is not fixed but can be increased by demonstrating to voters how the actions of a incumbent affect their welfare.

A related line of inquiry focuses on the importance of the information source or dissemination mode as opposed to its political content. For example, there is growing evidence that electoral debates broaden knowledge about politicians (Bidwell, Casey, and Glennerster, 2020; Brierley, Kramon, and Ofosu, 2020; Bowles and Larreguy, 2020), especially opposition leaders (Platas and Raffler, 2021). Similarly, information disseminated via mass media seems to be rather effective in 
supporting accountability processes (Aker, Collier, and Vicente, 2017), arguably because it supports voter coordination (Larreguy, Marshall, and Snyder Jr., 2020).

Another line of inquiry is the timing of the information dissemination efforts. Grossman, Michelitch, and Prato (2021), for example, argue that politician performance information can maximize impact if it is shared early, regularly and predictably throughout the electoral cycle. They find that early dissemination of politically salient information affected the slate of candidates on the ballot by changing the likelihood that potential challengers enter the race, incumbents' choice of running for reelection, and party leaders' nomination strategy.

That the information dissemination content, method, and timing can all be consequential highlights the importance of voters' information environment. While in most studies voters are simply assumed to be uninformed, a prior question is - why? If information provision would benefit an incumbent or her challenger, why is this information not provided in equilibrium? Certainly there are technological and resource constraints on politicians' ability to disseminate a message, for example limited media reach (Larreguy, Marshall, and Snyder Jr., 2020). Politicians may also manipulate the message or its dissemination for political advantage, i.e., through the direct control of media sources (Peisakhin and Rozenas, 2018), the manipulation of media licensing (Boas and Hidalgo, 2011), or by spreading disinformation via social media (Badrinathan, 2021). Understanding how and what information voters see absent exogenous information provision represents an important next step in the study of information and accountability.

Greater transparency can improve accountability not only by improving voters' ability to reward and sanction, but also by affecting incumbent behavior while in office. In theory, if politicians' actions are not visible to voters, politicians have weaker incentives to act in the interest of voters. We note that comparatively less attention has been devoted to whether information provision to voters reduces shirking by politicians. Grossman and Michelitch (2018) conduct a field experiment that disseminates politician scorecards during a politician's term. They find that dissemination increased politician effort/performance, but only in ex-ante competitive constituencies. Similarly, Bobonis, Fuertes, and Schwabe (2016) find that Puerto Rican mayors whose municipal 
governments audit results were known to be released prior to elections, engaged in corruption at lower rates than municipal governments whose audits were known to be made public after the elections. These studies suggest that increasing voter information in a matter that is visible to politicians can reduce the moral hazard of politicians, consistent with theories of accountability.

The close focus on voter information (and increasingly - misinformation) may lead us to miss other manifestations of accountability or its absence. First, there may exist barriers to the attribution of specific outcomes to politicians, in part because politicians may actively undermine trans-

parency efforts (Cruz, Keefer, and Labonne, 2021), or because voters put undue weight on highly visible service outcomes, such as infrastructure projects (Harding, 2015). Second, politicians' responsiveness to the public is likely (also) a function of the institutional environment, including campaign finance laws (Ruiz, 2020) and election quality (Rueda and Ruiz, 2020).

In sum, there is growing evidence that voters can and do rationally use political performance information to inform voting decisions, but only under certain conditions. Voters are more likely to do so when the information is reliable, timely, and salient, and when the method of dissemination allows for voter coordination. Given these observations, more research is needed to understand why candidates, parties, or the media do not seek to provide information to voters when it is advantageous to do so, or how these actors amplify or counter information. Relatedly, more research is needed to better understand incumbents' response-for example, increasing vote buying efforts or exerting greater effort— to greater transparency of their performance. Additionally, distinguishing voter beliefs from vote choice may provide a better understand voting behavior, therefore helping to reconcile these mixed existing findings on information and accountability.

\subsection{Constituency Service}

A growing literature considers more quotidian interactions between politicians and citizens as a tool that citizens use to induce government responsiveness. While constituency service has long been studied in the US context (Fenno, 1978), these interactions between politicians and citizens may hold particular importance in low-capacity states with thinner services or less professionalized bureaucracies. 
However, two features of constituency service limit its ability to deliver services to the population. First, it is generally infeasible to scale service provision on the basis of contact between individual citizens and politicians (and party brokers) alone. In most settings, there are many of constituents for each politician. Second, with few politicians relative to constituents, understanding which citizens request or receive constituency services is important for understanding the degree to which constituency service shapes distributional outcomes.

Recent work uses ethnography (Paller, 2019) and a novel politician-shadowing research design (Bussell, 2020) to demonstrate that constituency service occupies a large portion of "what politicians do" and what citizens ask for. Moreover, studies of government responsiveness in autocracies suggests that constituency services is especially valuable when politicians' policymaking role is constrained or when weak (or non-existent) electoral institutions limit electoral accountability (Distelhorst and Hou, 2017; York, 2020).

Research of this type of interaction between politicians and voters suggests disadvantages to over-reliance on constituency services to achieve responsive governance. As mentioned, politicians are commonly (but not uniformly) differentially responsive to different (types of) constituents. These inequalities are often studied through audits or audit experiments. In line with evidence from the USA (e.g., Butler and Broockman, 2011), McClendon (2016) find that legislators in South Africa respond to same-race constituents at higher rates, a measure of responsiveness. Driscoll et al. (2018) similarly find class and racial biased response among (most, but not all) parliamentary candidates in Brazil. Understanding why and when we observe disparate responses by politiciansa promising avenue of future theoretical and empirical research—is important for understanding inequalities in government responsiveness.

Variation in politicians' response may reflect their personal tastes or prejudices. McClendon (2016) finds that the magnitude of politicians' racial biases in South Africa did not vary across their race or office and McAndrews et al. (2020) show co-ethnic bias persists when electoral incentives are removed. Prejudice based discrimination has been corroborated by a recent meta-analysis study of elite responsiveness to constituent communication (Costa, 2017). 
In some contexts, differential responsiveness arises from the electoral incentives of politicians. Driscoll et al. (2018) find that Brazilian candidates for the national legislature, concerned about alienating voters, discriminated against lower-class constituents after but not before the elections. Gaikwad and Nellis (2020) provide evidence that urban politicians discriminate against internal (domestic) migrants in India. They suggest a form of electorally-motivated statistical discrimination as a mechanism. This discrimination results from migrants' lower propensity to vote in destination-area elections. Yet, this statistical discrimination mechanism does not arise in all contexts. In other experiments, there is little evidence that politicians discriminate between highpropensity voters and non-voters even when these intentions are explicitly revealed (Bussell, 2019).

Politicians provide constituency services to those who approach them. Yet, in many contexts there are large inequalities in political access. Understanding which citizens choose to seek constituency services, can help illuminate critical questions about the distributional implications of constituency service. Kruks-Wisner (2018) advances a theory of claim-making based on citizens' aspirations and capabilities. She further demonstrates that citizen aspirations and capabilities to request service are shaped by past experience with the state. Closely related, Grossman, Michelitch, and Santamaria (2017) and Auerbach and Kruks-Wisner (2020) explain citizens' requests (or complaint making) as a function of their sense of (external) efficacy. Other studies focus on social or relational - as opposed to individual - characteristics of citizens. Bussell (2019) suggests citizens seek constituency service when they cannot access existing patronage networks. Ferrali et al. (2020) show the important role of one's social ties in learning about how to access politicians for constituency services.

Finally, we point to the growing availability of information and communication technologies (ICTs) to improve citizens' ability to scale constituency services. Most notably, the use of widespread complaint systems (e.g., 311 lines, or FixMyStreet app) reduces citizens' costs of filing a complaint or making a request. With the exception of Slough $(2020 b, c)$ - that conceptualizes complaint systems as a form of bureaucratic oversight, as discussed below-the existing literature treats such systems as interactions between citizens and politicians. Analyzing data from 311 lines 
(or the equivalent) allows for the study of variation in politician responsiveness to the complaints that emerge. Two recent studies, Christensen and Ejdemyr (2020) and Dipoppa and Grossman (2020) find that responsiveness - measured as the speed with which complaints are remediedincreases in the lead-up to elections in New York City and San Francisco and in the UK, respectively. Dipoppa and Grossman (2020) further show an increase in citizen complaint-making in the lead-up to elections that coincides with this increase in responsiveness.

Similar ICT complaint systems are increasingly available in some low- and middle-income countries. Efforts to expand related complaint systems have motivated several recent experiments, exploring who uses these services and testing whether communication technologies affect service delivery. For example, Grossman, Humphreys, and Sacramone-Lutz (2014, 2020) examine usage of SMS-based complaint systems that connects Ugandan constituents to their representatives in the national parliament. In a small-scale "framed" field experiment, they find that such a system—which was introduced in person—can have "flattening" effects, empowering the voices of the most marginalized (according to demographic classifications) and, in theory, reducing inequality in political access. However, when brought to scale, marginalized citizens participated less than non-marginalized citizens, in part because of the challenge of reaching (and mobilizing) marginalized populations in the absence of personalized appeals.

Relatedly, Grossman, Platas, and Rodden (2018) examine the creation of an ICT complaint systems in Uganda that facilitated citizen complaints to local politicians. The authors find only small, short-term effects on education and water services (but not other services). Examining the content of complaint messages, they find that less than a quarter of messages contained "actionable" requests and that responses by public officials underwhelmed citizens. Buntaine, Hunnicutt, and Komakech (2021) report similarly null results for a new ICT complaint system implemented by Kampala's municipal government. These works serve as models for future efforts to disentangle the distributional implications of complaint systems at a micro level and explore the conditions under which they may improve service delivery.

In sum, providing constituency services is an important part of politicians' job duties and cit- 
izens' expectations of politicians. However, there is growing evidence that constituency services are provided in ways that can deepen societal inequalities due to patterns of selection into seeking citizen service or differential treatment of citizens by politicians. Understanding the conditions under which new information technologies lower barriers to accessing constituency services may offer lessons for reducing inequalities in political access. However, we still lack the theory and evidence of when such complaint, inquiry, and reporting systems yield sustained improvements in service delivery more broadly. A further important direction for work on the extension of complaint systems should focus on when governments choose to adopt these systems and characterizing variation in both citizen usage of and politician response to citizen complaints.

\section{Dyad \#2: Politicians and Bureaucrats}

In considering how citizen preferences for public goods or services map onto outputs, it is important to consider the role of bureaucrats in producing these public goods and services. A large literature in political science and public administration considers the relationships between politicians and bureaucrats. We first review evidence on politicians' ability to select bureaucrats and incentivize bureaucrats to exert greater effort. We consider here the distinction between patronage and civil service systems. We then consider "smaller" personnel policies or reforms intended, again, to elicit bureaucratic effort or improve bureaucratic selection. Then, as in the case of the citizen-politician dyad, we consider more day-to-day interactions between politicians and bureaucrats, emphasizing political oversight of bureaucrats.

\subsection{Personnel Systems: Civil Service vs. Patronage}

Classic studies of the relationships between bureaucrats and politicians focus on politicians' power to hire and fire bureaucrats. The ability to recruit high-skilled workers into public service, and elicit effort from civil servants, are key challenges that all governments face.

When politicians face few constraints in hiring bureaucrats, they may choose to offer public jobs as a reward for support or loyalty. If these supporters' preferences are closer to those of the politician, the congruence of preferences between the politician and bureaucrat may limit ideo- 
logical conflict in policymaking (Spenkuch, Teso, and $\mathrm{Xu}, 2021$ ). Moreover, if a politician can freely dismiss bureaucrats, prevent their promotion or assign them to undesirable locations, bureaucrats may have greater incentives to exert effort. Yet, providing politicians with free range to hire, promote, demote, relocate and fire bureaucrats comes with costs. First, conditioning jobs on political support instead of expertise arguably reduces bureaucratic quality to handle the demands of "complicated" programs or services. Second, political appointees have on average, shorter time horizons, which may further limit (endogenously) acquisition of bureaucratic expertise (Gailmard and Patty, 2007). Further, higher frequency (or a larger share) of government turnover can yield temporary reductions in service delivery (Toral, 2020).

Existing literature typically classifies bureaucratic personnel systems as (merit-based) civil service or patronage-based. Civil service systems include: (1) a set of constraints on who may be hired as a bureaucrat (i.e., through the use of merit exams) and (2) limits on the removal of bureaucrats. Much literature focuses on when politicians adopt civil service systems, relinquishing some degree of control over the hiring or firing of bureaucrats (Geddes, 1994).

However, in practice, most bureaucracies exist somewhere between the two extremes. Even in countries with strong and enforced civil service protections, there generally exist political appointees in high-level posts. In some civil service systems, politicians may adopt hiring practicesfor example, using contractors to fill public administration vacancies-explicitly to circumvent the insulating protections of the civil service. In one of the few studies to measure the extent of this practice, Pierskalla and Sacks (2020) find that the creation of local elections in Indonesia led to an expansion of teachers hired as contractors. As such, in contrast to the theoretical construct of civil services vs. patronage systems, most countries fall somewhere on a continuum between the two extremes.

Given our review's focus, a relevant question is: how do attributes of the personnel system affect the delivery of public goods and services in developing countries? The evidence is, again, mixed. Duflo, Dupas, and Kremer (2015) find that compared to permanent hires, contract teachers increase students' leaning and test scores in Kenya. This, however, can reflect short-term gains. 
Within a patronage system, Aktari, Moreira, and Trucco (2020) provide evidence that, when mayors lose power in Brazil, municipal schools experience higher turnover of teachers and headmasters. ${ }^{3}$ Mayoral losses further negatively affect down-stream student performance on standardized tests, arguably through the turnover of teachers and headmasters. Toral (2019) extends this finding by showing that both effects emerge most strongly in schools with appointed (as opposed to nonappointed) school headmasters. Further, consistent with the idea that methods of selection that are not politically controlled may generate greater bureaucratic expertise or experience, schools with non-politically appointed headmasters appear to exhibit stronger student performance on national standardized exams.

The structure of bureaucratic hiring may also influence how politicians choose to allocate budgets to public goods and services. Using historical evidence from civil service reform in US states Ujhelyi (2014) find that state governments appropriated more funds to local governments, ostensibly to bypass reformed state bureaucracies. Civil service reforms may also discipline political budget cycles by constraining politicians' ability to expand public payrolls in preparation for elections. Adoption of a civil service system may also change politicians' allocation of funds over time. Bostashvili and Ujhelyi (2019) suggest that pre-election cycles of spending on roads (infrastructure) were eliminated subsequent to the adoption of civil-service systems in US states.

\subsection{Personnel Policies beyond Civil Service}

Can reforms to personnel policies beyond civil service systems shape the composition and public service outputs of the bureaucracy? Here the literature explores public sector remuneration schemes and various non-remunerative incentives that may affect bureaucratic quality via selection or effort.

Politicians can influence personnel policy by setting public sector wages and other (e.g., retirement) benefits in regular budgetary appropriations. Following Finan, Olken, and Pande (2017), three empirical patterns related to public sector wage premium - the difference in average pay in

\footnotetext{
${ }^{3}$ This is consistent with other characterizations of Brazilian municipal governments as patronage-laden (Colonnelli, Prem, and Teso, 2020).
} 
the public minus the private sector-are of note. First, there exists substantial cross-national variation in public-sector wage premium. Second, public sector wage premium is decreasing in per capita GDP: it is greatest in low-income countries. Third, within countries, public sector wage premium is decreasing in education. We note that the logic for these political decisions remains under theorized. In addition, it is hard to measure how public payrolls affect selection into the bureaucracy using macro-level data.

Dal Bó, Finan, and Rossi (2013) thus conduct an experiment randomizing the wages of Mexican community development agents. In line with theory, they find that higher wages increased the size and quality (measured using outside wages and education attainment) of the candidate pool. Importantly, they further show that these wage incentives simultaneously increase the public service motivation of applicants. This suggests a positive correlation between public service motivation and ability (though see Hanna and Wang (2017) who find that screening public servants on ability, may select individuals who are less pro-social in incentivized experiments in India).

Ashraf et al. (2020) examine the role of career opportunities within the civil service. In an experiment to staff a new community health program in rural Zambia, the government randomized recruitment of community health workers by advertising civil service positions as opposed to "status-quo" NGO positions. The civil service positions yielded more highly qualified pool of applications, and for sufficient quality, there was no trade-off with pro-sociality. Critically, they identify downstream effects on service delivery: community health workers recruited via the civil service advertisements perform at a higher level on a sequence of performance outcomes. In addition to interventions aimed at bureaucratic selection, changing bureaucrats' incentives may induce them to work harder. One policy option in this context is pay-for-performance (P4P). Appealing to extrinsic motivations, these compensation schemes typically reward inputs (for example, presence and conduct of public-sector nurses and teachers). A key concern is that $\mathrm{P} 4 \mathrm{P}$ will reduce effort by eroding intrinsic motivation, or that bureaucrats would invest only in visible actions on which they are rewarded (Benabou and Tirole, 2003). Leaver et al. (2021) use an RCT in the education sector in Rwanda to test the effort margins of pay-for-performance (here, rewarding the top 20 percent of 
teachers with extra pay using a metric that equally weights learning outcomes in teachers' classrooms). They find that teachers working under $\mathrm{P} 4 \mathrm{P}$ contracts elicited better performance from their students than teachers working under fixed pay contracts. Other notable studies of P4P schemes in education include Loyalka et al. (2019) in China, and Gilligan et al. (2021) in Uganda.

High-powered incentive schemes are not always a feasible option when pay scales are subject to strict civil service regulations with little room for rewarding performance. Khan, Khwaja, and Olken (2019) investigate therefore an alternative incentive: whether performance based postings to preferred jurisdictions can increase bureaucratic effort. They design a tournament mechanism among tax collectors in Punjab, Pakistan. Tax collectors submit their preferred assignments and assignments are made on the basis of performance rank. Implementation of this scheme appears to increase effort dramatically: tax collectors assigned to the tournament mechanism collected an additional $30-41 \%$ of control group tax revenues.

To sum up, where a bureaucracy lies on the continuum between civil service system and a patronage system is consequential for the delivery of public services and private benefits. However, wholesale reforms of bureaucracies are politically challenging (though see Huber and Ting (2021) who theorize about politicians' incentives to implement civil service reforms). Instead, "smaller" personnel policies may offer a partial solution for building bureaucratic quality or improving bureaucratic outputs. Compensation schemes, including both regular public sector wages and the creation higher-powered incentives, represent one clear instrument through which politicians can alter bureaucratic selection and effort with potentially large distributional consequences within countries. There is indeed growing evidence that personnel policies within existing civil service systems can affect the recruitment, effort, and outputs of bureaucrats in ways that improve service delivery outcomes. Thus, studying how politicians decide on these schemes represents one important avenue for better incorporating politicians into the study of personnel policy and its consequences. To this end, the studies we review generally involved collaboration with a government partner. However, we know much less about when and why politicians pursue these types of personnel interventions or innovations outside the context of collaborative projects with researchers. 


\subsection{Bureaucratic Oversight by Politicians}

Politicians routinely aim to induce bureaucrats to work or pursue the politicians' goals through monitoring. The effects of monitoring on bureaucrats' behavior may be conditioned by personnel policies or incentives. For example, if politicians detect bureaucratic errors, personnel policy generally constrains the recourse available to politicians. We examine current evidence on the effects of monitoring or oversight across contexts with varying personnel institutions.

Programs and policies that increase the rate at which politicians monitor bureaucratic service providers suggest that monitoring may reduce corruption, increase effort and ultimately promote better public service delivery. For example, Olken (2007) shows that top-down monitoring of bureaucrats reduced corruption in the execution of public works projects. This and similar empirical findings are consistent with the idea that monitoring can bring bureaucratic behavior closer to the politician's ideal. These findings raise three important questions. First, what are the limits to politicians' oversight effectiveness? Second, under what conditions does political oversight yield better service provision as opposed to other outcomes (i.e., 'kickbacks' to politicians, rent extraction, and negative selection into the bureaucracy)? And third, if monitoring is effective, why is it under-provided?

Two common theoretical assumptions hold that monitoring is constrained by (1) the (effort) costs of monitoring bureaucrats and (2) relative levels of expertise - bureaucrats are generally more knowledgeable about programs than politicians. Recent experimental evidence aims to manipulate these parameters directly. Callen et al. (2020) examine monitoring of health care workers by inspectors in Punjab, Pakistan by introducing a smartphone-based monitoring app. The app reduces the costs of collecting and processing the information while simultaneously verifying the effort exerted by inspectors. They find that relative to status-quo paper monitoring, the app increases rates of inspection (inspector effort) by $74 \%$ and also reduces the absenteeism of health care workers. Similarly, Dal Bó et al. (2021) find that a new mobile app that allows supervisors to track public agriculture extension agents across space, increased the share of farmers visited in the previous week by 22 percent. 
Raffler (2020) examines instead a program meant to remedy disparities in politician and bureaucratic expertise by training Ugandan local councilors to monitor bureaucrats. The intervention she studies introduced a bundle of information about their monitoring responsibilities and technical details about "how to monitor," including how to read a budget, etc. She finds that such training increases monitoring effort and user satisfaction with service delivery, but only in constituencies controlled by the opposition party. The distinction between government- and opposition-controlled areas in Raffler (2020) points to the potential importance of politicians' objectives in influencing: (1) when they choose to monitor bureaucrats and (2) the outcomes of this monitoring. Politicians may monitor to increase bureaucrats' performance as service providers but are likely to do so only to the extent that they value service delivery. Raffler contends that in ruling party areas, at least in the context of a dominant party regime, politicians fear uncovering corruption and refrain from monitoring. Other work suggests that politicians may even use oversight authority to direct bureaucrats to extract rents (Brierly, 2020). Rasul and Rogger (2008) similarly find that autonomous bureaucrats complete a higher proportion of projects, while greater political oversight depresses completion rates.

If monitoring impacts' bureaucrats' behavior, what explains variation in politicians' monitoring efforts? Gulzar and Pasquale (2017) find that politicians monitor bureaucrats to improve service delivery when they can claim credit for doing so. Leveraging a mismatch between electoral constituencies and bureaucratic jurisdictions in India, they show that bureaucrats supervised by a single politician are more likely than those supervised by multiple politicians to increase the reach of the National Rural Employment Guarantee Scheme (NREGS). These differences between single and multiple principal districts attenuate as the size of the constituency increases, suggesting of a credit-claiming electoral mechanism underlying these preferences for improved NREGS implementation.

Collectively, these works suggest that political oversight of bureaucrats can change bureaucrats' behavior. Yet, the principal's monitoring of an agent responsible for producing public goods can, in theory, improve or worsen service delivery. Grossman and Hanlon (2014), for example show 
that when agent's opportunity costs are sufficiently large, increasing monitoring efforts can worsen the delivery of public goods by inducing high-skilled individual to select out of public service.

Establishing a stronger evidence base on politician preferences for public goods provision represents an important next step to understanding which forms of monitoring are most likely, and when enhancements to political oversight does in fact improve service delivery. To the extent that service provision is a goal because it is desired by citizens, research considering how public service delivery enters politicians' objective can provide greater clarity about the relationship between bureaucratic oversight and public goods and service outcomes.

In sum, while recent literature has expanded our understanding of the effects of oversight, more work is needed to understand politicians' incentives and choices to adopt monitoring institutions. Recent theoretical and empirical work rejects the idea that politicians always favor a more effective civil service. For example, Gottlieb (2021) argues that investments politicians make in the capacity of the bureaucracy is endogenous to incumbents' electoral considerations. Other work considers politicians' distributive considerations when designing oversight institutions (Slough, 2020c). Finally, more works is needed on the (strategic) response of bureaucrats to oversight. While much work assumes that additional monitoring drives higher effort, it may also cause (some) bureaucrats to transfer, or even exit the public sector. We view these questions as important considerations moving forward.

\section{Dyad \#3: Bureaucrats and Citizens}

In most settings, citizens' most common interaction with the state occurs through routine interactions between citizens and front-line service providers. A growing literature focuses on bureaucratic responses to citizen requests for service and understanding when bureaucrats internalize citizen welfare to improve service provision.

\subsection{When do Bureaucrats Internalize Citizen Welfare?}

An active recent literature asks: under what conditions do front-line bureaucrats exert the effort necessary to deliver services to citizens? Consider two answers advanced in the recent literature. 
First, bureaucratic incentives for promotion or retention may induce preferences for service provision for some or all citizens. Second, bureaucrats may have a bias for serving some citizens over others, independent of oversight or citizen pressures. For example, it is commonly suggested that bureaucratic embeddedness with the citizens that they are tasked to serve drives bureaucrats to exert greater effort in implementing policies and delivering services (Pepinsky, Pierskalla, and Sacks, 2017). For example, Xu (2021) shows that Indian districts with Indian as opposed to British district officers experienced $15 \%$ lower deaths during the flu pandemic of 1918 . He contends that Indian district officers achieved these reductions by providing more relief to citizens, ostensibly a measure of bureaucratic effort. Note that embeddedness can be defined not only in terms of a shared identity (e.g., ethnicity or race), but also in terms of home-region. Relatedly, Bhavnani and Lee (2017) find that Indian Administrator Service bureaucrats from the state they serve increase access to high school education.

It is not a priori clear that bureaucratic preferences over service recipients are necessarily driven by shared (identity) characteristics. A recent experimental literature has emerged to study discrimination through audit experiments. These experiments are most common in developed settings where email communication between citizens and front-line service providers is regular (e.g., White, Nathan, and Faller, 2014). In a rare middle-income context, Slough (2020b) finds evidence of bureaucratic discrimination by citizen (petitioner) attributes, but not by shared region. In these experiments, differential treatment of citizens by bureaucrats may reinforce inequalities in access to vote or in provision of social welfare programs even if they are not obviously attributable to shared identity or connections between bureaucrats and the citizens they serve.

Much of our understanding of the consequences of bureaucratic embeddedness, favoritism, or discrimination starts from assumptions about which citizens bureaucrats might wish to prioritize. For example, bureaucrats may mirror societal biases toward some groups over others. While these assumptions may well be borne out in some contexts, there is a need for a more thorough development of other mechanisms that may account for disparities in bureaucrats' treatment of citizens, and empirical determination of which mechanisms are at work. For example, it is possible that 
bureaucrats better serve co-ethnic/co-regional citizens not due to taste-based discrimination, but because they have better local knowledge or technologies with which to serve in-group members.

Consistent with this interpretation, Xu, Bertrand, and Burgess (2020) use peer performance appraisals inputs to test the effects of location-based embeddedness. They find that embedded IAS bureaucrats perform worse than comparable officers who are allocated to non-home states. Bureaucrats assigned to their home states were found to be more corrupt, less able to withstand illegitimate political pressure, less pro-poor and to receive lower performing assessment, even as they may end up (arguably) delivering better service outcomes (Bhavnani and Lee, 2017). Identifying the precise mechanism at hand could answer questions about how oversight or incentives could reduce disparities, and under what conditions embeddedness be productively harnessed to improve service provision via reallocation of bureaucratic across jurisdictions.

In sum, theoretically, embeddeness is related to the fact that governments must decide how to allocate civil servants across space. This decision is subject to the classic trade-off between delegation and control (Aghion and Tirole, 1997). If bureaucrats are assigned to familiar environments, they could use their informational advantage to better adapt to local conditions. The same informational advantage, however, might also be exploited for private gain. How politicians balance these trade-offs and why the assignment of bureaucrats across space affects bureaucratic performance differently in different contexts remains understudied.

\subsection{Citizen Oversight of Frontline Bureaucrats}

In light of the growing recognition of the difficulty citizens face in holding politicians to account (discussed above), a natural question arises: can citizens pressure service providers directly to improve service provision? In a so-called "short-route" to accountability, better service provision is achieved through various forms of collective action, individual appeals, or other forms of social pressure of bureaucrats (Kosack and Fung, 2014). In recent years, a growing number of programs have sought to increase individual or collective capacity to exert (bottom-up) pressure on frontline service providers to improve services, to mixed results. Below we review these studies and point to several problems with the underlying theoretical assumptions of these attempts. 
Björkman and Svensson (2009) report the results of an experiment to implement communitybased monitoring of frontline healthcare providers in rural Uganda. The intervention provided community members report cards on health service outputs and aimed to facilitate collective monitoring of service providers. One year later, the authors find higher health care utilization and reductions in child mortality in treatment communities (villages). Approximately a decade later, Arkedis et al. (2019), Christensen et al. (2021), and Raffler, Posner, and Parkerson (2020) report the results of experiments on community-based monitoring of healthcare providers in three countries in sub-Saharan Africa and in Asia to mixed results. These "replication" studies recover mixed evidence that this type of citizen oversight can improve perceptions of health-care providers, health care utilization, and improve health outcomes. Across the replication experiments, information as opposed to collective action - seems most likely to drive any observed effects. Raffler, Posner, and Parkerson (2020) hypothesizes that said variation may be driven by differences in baseline (control) health outcomes.

Specifically, there are growing concerns about the sustainability of bottom-up monitoring program (Banerjee et al., 2010) mainly due to collective action problems (Mansuri and Rao, 2012) as well as a growing recognition of the power and status asymmetry that make villagers reluctant to confront frontline service providers, partly due to low efficacy (Lieberman and Zhou, 2021) and in part due to fear of retribution (Kaawa-Mafigiri and Walakira, 2017).

Other related interventions, which focus only on information provision absent the community monitoring (collective action) components, similarly find mixed results. Andrabi, Das, and Khwaja (2017) examine the effects of a campaign that disseminated report cards on public and private schools in Pakistan to parents. They find increases in test scores and enrollment subsequent to the disclosure of report cards. While parents became better informed, they find suggestive evidence that improvements in educational outcomes come through school-level improvements in service provision (more qualified teachers in public schools and less break time) as opposed to additional parental effort. For example, Lieberman, Posner, and Tsai (2014) find no evidence that informing parents in Kenya about their children's (relative) reading and numeracy skills changed citizen 
behavior, school services, or school outputs, though these parents had fewer available strategies through which to respond to the evidence. We also note possible negative effects of said information campaigns, including making schools more selective in admission requirements, teaching to the test, and strategically excluding weaker students from taking standardized tests (Cilliers, Mbiti, and Zeitlin, 2021).

There is danger, in our view, in equating interventions that aim to exogenously increase citizen oversight of frontline bureaucrats with endogenous variants of this oversight. If individual or collective oversight can increase the effort of service providers, individuals and communities may well have already adopted this oversight. Indeed, works like Tsai (2007) show a role for some forms of social solidarity groups like churches in improving service provision in China. Existing levels of service provision-however good or bad-represent, in equilibrium, endogenously adopted citizen oversight practices. Further, community monitoring is a public good potentially subject to collective action problems. Thus, exogenously increased community monitoring levels may subside when when encouragement from central governments or development agencies is removed.

Moving forward, we encourage researchers to measure directly the barriers that communities may face to increase oversight of frontline service providers shy of external encouragement. We suggest further consideration of the measurable implications of citizen oversight. In principle, bureaucratic effort and thus service provision may be sustained by the mere prospect of citizen oversight in the instance of poor service provision. Slough (2020b) focuses on this type of forwardlooking behavior by frontline service providers as a driver of unequal treatment of citizens. If this is the case, it is hard to make assertions about the efficacy/non-efficacy of citizen oversight of service providers, especially if we do not observe instances of collective action or complaint directly. As such, better measurement of perceived oversight (in the eyes of bureaucrats) or oversight potential (by citizens) may be important for characterizing this "short route" to accountability. Beyond innovation in measurement, describing these dynamics generally requires clear exposition of an equilibrium and its empirical implications. 


\section{The Path Forward}

There is much to be learned from studies of the three dyads that we presented above. However, we contend that consideration of interactions between all three actors in a single framework presents an important frontier in the study of government responsiveness and accountability in developing settings and beyond. As in the empirical literature we survey, the theoretical literature has generally emphasized dyadic interactions. Theoretical models that incorporate politicians, bureaucrats, and citizens (voters) are relatively rare, though this represents an active current research agenda.

For example, Fox and Jordan (2011), Yazaki (2018), and Li, Sasso, and Turner (2019) introduce models of electoral accountability that incorporate bureaucrats. Recent theories of service provision has considered citizen attempts to access government services. Ting (2021) introduces a novel framework to investigate the dynamics of service provision - specifically, the extent of policy benefits, investment administrative capacity, and program durability - that incorporates politicians as policymakers (principals), bureaucrats as service providers (agents), and citizens as service seekers. Slough $(2020 c)$ considers both the adoption and implications of bureaucratic oversight institutions. Her model incorporates information on citizen complaints as an input affecting whether politicians can address moral hazard problems of bureaucrats. She finds that reliance on citizen complaints as "fire alarms" can have divergent impacts on the state's ability to implement a service in a population that varies in its propensity to complain.

We argue that more widespread consideration of interactions between citizens, politicians, and bureaucrats in the empirical literature holds the potential to: (1) illuminate new mechanisms underlying (un)responsive governance; (2) reconcile some conflicting findings; and (3) inform the design of policy interventions aimed to increase responsiveness.

Key to these potential contributions is a more explicit acknowledgement of the equilibrium implications of these three-actor interactions. By focusing on the behavior of a single actor or, at most, a dyad of two actors, much of the evidence that we review offers "partial equilibrium" findings. In essence, dyadic analysis does not consider how the omitted actor may respond, and how that response may impact the observed data. The arguably more complete three-actor mod- 
els on both political accountability and service provision generally producing more ambiguous predictions and subtler implications for many of the core outcomes of interest than the existing two-actor models that inspire much of the empirical literature we present. By omitting consideration of other actors' behavior, theory suggests that we risk mischaracterizing the mechanisms at work and misinterpreting (commonly mixed) empirical findings. These issues could even lead to ill-advised policy prescriptions or interventions. We outline several recent approaches to this challenge, highlighting the benefits considering all three actors.

New mechanisms: Martin and Raffler (2021) propose a new explanation for the widespread observation of limited of voter updating on politician performance information provided by recent empirical studies of electoral accountability. They suggest that politicians' reliance on bureaucrats to "get things done" renders public goods outputs noisier signals that limit voters' ability to update on a politician's type given performance information. They test their framework using a factorial survey experiment in Uganda that varies both the signal of performance (good or bad roads), the bureaucrat's level of power, and information about the attribution of responsibility to politicians or bureaucrats. The authors find that respondents' attribution of responsibility to the politician for roads (and correspondingly hypothetical voting behavior) is attenuated when citizens are told that bureaucrats are responsible for implementation. While the theory considers only voters as strategic actors, these findings suggest that citizens, politicians, and bureaucrats are able to consider the dynamics of this three-actor accountability relationship. This study interjects a new mechanism—voters' joint attribution of responsibility between politicians and bureaucrats—into a large accountability literature generally focused more narrowly on voter-politician relations.

Reconciling conflicting findings: Building upon our understanding of the role of bureaucrats in accountability relations between voters and politicians, Slough (2020a) argues that when politicians and bureaucrats co-produce public goods, bureaucratic quality conditions the efficiency of politicians' public goods investments and thus their ability to signal their type to voters. Unlike Martin and Raffler (2021), Slough argues that strategic politicians anticipate voters' ability to infer politician type from the public goods signal and allocate funds to public goods (as opposed 
to rents) accordingly. This model yields four distinct equilibria that present at different levels of bureaucratic quality and have different observable implications. For example, a conventional account that suggests that "good" and "bad" politicians take different actions with respect to funding public goods-the focus of much of the electoral accountability literature-emerge only at moderately low levels of bureaucratic quality. Reanalyzing work on accountability and corruption in Brazil, Slough derives multiple tests of the model's predictions. She recovers evidence that is consistent with the idea that distinct equilibria will be present at different levels of municipal bureaucratic quality. This evidence is inconsistent with standard accounts that do not consider the bureaucracy or those assume voters to be uninformed. The study's finding of multiple equilibria helps to reconcile mixed evidence on the effects of information and accountability.

New policy implications: Slough (2020b) revisits studies of bureaucratic discrimination in the provision of public services. Here, citizen complaints about poor service provision increase oversight of bureaucrats by their principals (i.e., a politician). Anticipating the possibility of oversight by a political principal, bureaucrats provide better service ex-ante to citizens that are most likely to complain. She tests this mechanism-relative to existing alternatives-using an audit experiment of local bureaucrats administering Colombia's two largest social service programs. She finds that bureaucrats are more likely to provide information to middle- rather than lower-class citizens and residents over internal migrants. However, this bias is only present on tasks for which politician oversight is most likely and for the more politicized of the two programs. The key insight is the potential for oversight by the politician in response to citizen complaints drives at least some bureaucratic biases. The paper suggests that empowering (more) citizens to complain at lower cost can both improve service provision and reduce inequalities stemming from bureaucratic discrimination. This implication is distinct from existing suggestions to alter bureaucratic selection or to increase oversight to reduce such discrimination.

In this article, we reviewed the current body of work on government responsiveness in low- and middle-income countries, focusing in particular on theory and evidence that can help explain variation in the provision of public services across space and groups. Following much of the existing 
literature, we organized our review around three distinct dyadic relationships involving politicians, bureaucrats, and citizens. We have then presented a rationale for considering interactions between all three actors in a single framework to better characterize the foundations of government responsiveness. This emphasis on three-actor interactions calls for a tighter link between theory and empirics. In particular, differentiating equilibrium from partial equilibrium implications is useful for both theory and policy. It arguably better characterizes the nature of these interactions, but it is also important for designing and assessing new (or modified) interventions intended to improve the delivery of public goods and services in accordance with citizen preferences. 


\section{References}

Adida, Claire, Jessica Gottlieb, Eric Kramon, and Gwyneth McClendon. 2020. "When Does Information Influence Voters? The Joint Importance of Salience and Coordination." Comparative Political Studies 53 (6): 851-891.

Aghion, Philippe, and Jean Tirole. 1997. "Formal and real authority in organizations." Journal of political economy 105 (1): 1-29.

Aker, Jenny C, Paul Collier, and Pedro C Vicente. 2017. "Is information power? Using mobile phones and free newspapers during an election in Mozambique." Review of Economics and Statistics 99 (2): 185-200.

Aktari, Mitra, Diana Moreira, and Laura Trucco. 2020. "Political Turnover, Bureaucratic Turnover, and the Quality of Public Services." American Economic Review (forthcoming).

Andrabi, Tahir, Jishnu Das, and Asim Ijaz Khwaja. 2017. "Report Cards: The Impact of Providing School and Child Test Scores on Educational Markets." American Economic Review 107 (6): 1535-1563.

Arkedis, Jean, Jessica Creighton, Akshay Dixit, Archon Fung, Stephen Kosack, and Dan Levy. 2019. "Can Transparency and Accountability Programs Improve Health? Experimental Evidence from Indonesia and Tanzania." HKS Working Paper No. RWP19-020.

Ashraf, Nava, Oriana Bandiera, Edward Davenport, and Scott S. Lee. 2020. "Losing Prosociality in the Quest for Talent? Sorting, Selection, and Productivity in the Delivery of Public Services." American Economic Review 110 (5): 1355-1394.

Ashworth, Scott. 2012. "Electoral accountability: recent theoretical and empirical work." Annual Review of Political Science 15: 183-201.

Auerbach, Adam Michael, and Gabrielle Kruks-Wisner. 2020. "The geography of citizenship practice: How the poor engage the state in rural and urban india." Perspectives on Politics 18 (4): 1118-1134.

Badrinathan, Sumitra. 2021. "Educative Interventions to Combat Misinformation: Evidence From a Field Experiment in India." American Political Science Review (forthcoming).

Banerjee, Abhijit, Nils T Enevoldsen, Rohini Pande, and Michael Walton. 2020. "Public Information is an Incentive for Politicians: Experimental Evidence from Delhi Elections." National Bureau of Economic Research w26925.

Banerjee, Abhijit V, Rukmini Banerji, Esther Duflo, Rachel Glennerster, and Stuti Khemani. 2010. "Pitfalls of Participatory Programs: Evidence from a Randomized Evaluation in Education in India." American Economic Journal: Economic Policy 2 (1): 1-30.

Beekman, Gonne, Erwin Bulte, and Eleonora Nillesen. 2014. "Corruption, investments and contributions to public goods: Experimental evidence from rural Liberia." Journal of Public Economics 115: 37-47. 
Benabou, Roland, and Jean Tirole. 2003. "Intrinsic and extrinsic motivation." The review of economic studies 70 (3): 489-520.

Bhandari, Abhit, Horacio Larreguy, and John Marshall. 2021. "Able and Mostly Willing: An Empirical Anatomy of Information's Effect on Voter-Driven Accountability in Senegal." American Journal of Political Science (forthcoming).

Bhavnani, Rikhil R., and Alexander Lee. 2017. "Local Embeddedness and Bureaucratic Performance: Evidence from India." The Journal of Politics 80 (1): 71-87.

Bidwell, Kelly, Katherine Casey, and Rachel Glennerster. 2020. "Debates: Voting and Expenditure Responses to Political Communication.” Journal of Political Economy 128 (8): 2880-2924.

Björkman, Martina, and Jakob Svensson. 2009. "Power to the People: Evidence from a Randomized Field Experiment on Community-Based Monitoring in Uganda*." The Quarterly Journal of Economics 124 (2): 735-769.

Bleck, Jaimie, and Nicolas Van de Walle. 2013. "Valence Issues in African Elections Navigating Uncertainty and the Weight of the Past." Comparative Political Studies 46 (11): 1394-1421.

Boas, Taylor C., and F. Daniel Hidalgo. 2011. "Controlling the Airwaves: Incumbency Advantage and Community Radio in Brazil.” American Journal of Political Science 55 (4): 869-885.

Bobonis, Gustavo J, Luis Cámara R Fuertes, and Rainer Schwabe. 2016. "Monitoring Corruptible Politicians." The American Economic Review 106 (8): 2371-2405.

Bostashvili, David, and Gergely Ujhelyi. 2019. "Political budget cycles and the civil service: Evidence from highway spending in US States." Journal of Public Economics 175: 17-28.

Bowles, Jeremy, and Horacio Larreguy. 2020. "Who Debates, Who Wins? At-Scale Experimental Evidence on the Supply of Policy Information in a Liberian Election." Unpublished manuscript.

Brierley, Sarah, Eric Kramon, and George Kwaku Ofosu. 2020. "The Moderating Effect of Debates on Political Attitudes." American Journal of Political Science 64 (1): 19-37.

Brierly, Sarah. 2020. "Unprincipled Principals: Co-opted Bureaucrats and Corruption in Local Government in Ghana.” American Journal of Political Science 64 (2): 209-222.

Buntaine, Mark T, Patrick Hunnicutt, and Polycarp Komakech. 2021. "The challenges of using citizen reporting to improve public services: A field experiment on solid waste services in Uganda." Journal of Public Administration Research and Theory 31 (1): 108-127.

Bussell, Jennifer. 2019. Clients and Constituents: Political Responsiveness in Patronage Democracies. New York: Oxford University Press.

Bussell, Jennifer. 2020. "Shadowing as a Tool for Studying Political Elites.” Political Analysis 28: 469-486. 
Butler, Daniel M., and David E. Broockman. 2011. "Do Politicians Discriminate Against Internal Migrants? Evidence from Nationwide Field Experiments in India." American Journal of Political Science 55 (3).

Callen, Michael, Saad Gulzar, Ali Hasanain, Muhammad Khan, and Arman Rezaee. 2020. "Data and policy decisions: Experimental evidence from Pakistan." Journal of Development Economics 146: 102523.

Chong, Alberto, Ana L. De La O, Dean Karlan, and Leonard Wantchekon. 2015. "Does Corruption Information Inspire the Fight or Quash the Hope? A Field Experiment in Mexico on Voter Turnout, Choice, and Party Identification.” The Journal of Politics 77 (1): 55-71.

Christensen, Darin, Oeindrila Dube, Johannes Haushofer, Bilal Siddiqi, and Maarten J Voors. 2021. "Building Resilient Health Systems: Experimental Evidence from Sierra Leone and the 2014 Ebola Outbreak." Quarterly Journal of Economics (forthcoming).

Christensen, Darin, and Simon Ejdemyr. 2020. "Do Elections Improve Constituency Responsiveness? Evidence from US Cities." Political Science Research and Methods 8 (3): 459-476.

Cilliers, Jacobus, Isaac M Mbiti, and Andrew Zeitlin. 2021. "Can public rankings improve school performance? Evidence from a nationwide reform in Tanzania." Journal of Human Resources (forthcoming).

Colonnelli, Emanuele, Mounu Prem, and Edoardo Teso. 2020. "Patronage and Selection in Public Sector Organizations.” American Economic Review 110 (10).

Costa, Mia. 2017. "How Responsive are Political Elites? A Meta-Analysis of Experiments on Public Officials.” Journal of Experimental Political Science 4 (3): 241-254.

Cruz, Cesi, Philip Keefer, and Julien Labonne. 2021. "Buying informed voters: new effects of information on voters and candidates." The Economic Journal 131 (635): 1105-1134.

Dal Bó, Ernesto, Frederico Finan, and Martín A. Rossi. 2013. "Strengthening State Capabilities: The Role of Financial Incentives in the Call to Public Service*." The Quarterly Journal of Economics 128 (3): 1169-1218.

Dal Bó, Ernesto, Frederico Finan, Nicholas Y Li, and Laura Schechter. 2021. "Information Technology and Government Decentralization: Experimental Evidence from Paraguay." Econometrica 89 (2): 677-701.

Dipoppa, Gemma, and Guy Grossman. 2020. "The Effect of Election Proximity on Government Responsiveness and Citizens' Participation: Evidence From English Local Elections." Comparative Political Studies 53 (14): 2183-2212.

Distelhorst, Greg, and Yue Hou. 2017. "Constituency Service under Nondemocratic Rule: Evidence from China." The Journal of Politics 79 (3): 1024-1040.

Driscoll, Amanda, Gabriel Cepaluni, Feliciano de Sá Guimarães, and Paolo Spada. 2018. "Prejudice, Strategic Discrimination, and the Electoral Connection: Evidence from a Pair of Field Experiments in Brazil." American Journal of Political Science 62 (4): 781-795. 
Duflo, Esther, Pascaline Dupas, and Michael Kremer. 2015. "School governance, teacher incentives, and pupil-teacher ratios: Experimental evidence from Kenyan primary schools." Journal of Public Economics 123: 92-110.

Dunning, Thad, Guy Grossman, Macartan Humphreys, Susan D. Hyde, Craig McIntosh, and Gareth Nellis, eds. 2019. Information, Accountability, and Cumulative Learning: Lessons from Metaketa I. New York: Cambridge University Press.

Fearon, James D. 1999. "Electoral Accountability and the Control of Politicians: Selecting Good Types versus Sanctioning Poor Performance.” In Democracy, Accountability and Representation, ed. Adam Przeworski, Susan C. Stokes, and Bernard Manin. Cambrige, MA: Cambrige University Press pp. 55-97.

Fenno, Richard F. 1978. Home Style: House Members in their Districts. Boston, MA: Little Brown.

Ferrali, Romain, Guy Grossman, Melina R Platas, and Jonathan Rodden. 2020. "It Takes a Village: Peer Effects and Externalities in Technology Adoption." American Journal of Political Science 64 (3): 536-553.

Ferraz, Claudio, and Frederico Finan. 2008. "Exposing Corrupt Politicians: The Effects of Brazil's Publicly Released Audits on Electoral Outcomes." Quarterly Journal of Economics 123 (2): 703-745.

Finan, Frederico, Benjamin Olken, and Rohini Pande. 2017. "The Personnel Economics of the Developing State.' In Handbook of Field Experiments, ed. Abhijit Banerjee, and Esther Duflo. Vol. 2 Oxford, UK: North-Holland pp. 467-514.

Fox, Justin, and Stuart V. Jordan. 2011. "Delegation and Accountability." Journal of Politics 73 (3): 831-844.

Gaikwad, Nikhar, and Gareth Nellis. 2020. "Do Politicians Discriminate Against Internal Migrants? Evidence from Nationwide Field Experiments in India." American Journal of Political Science (forthcoming).

Gailmard, Sean, and John Patty. 2007. "Slackers and Zealots: Civil Service, Policy Discretion, and Bureaucratic Expertise.” American Journal of Political Science 51 (4): 873-889.

Galimard, Sean, and John W. Patty. 2012. "Formal Models of Bureaucracy." Annual Review of Political Science 15: 353-377.

Geddes, Barbara. 1994. Politician's dilemma: building state capacity in Latin America. Number 25 Univ of California Press.

Gilligan, Daniel O, Naureen Karachiwalla, Ibrahim Kasirye, Adrienne M Lucas, and Derek Neal. 2021. "Educator incentives and educational triage in rural primary schools." (forthcoming).

Golden, Miriam, and Brian Min. 2013. "Distributive Politics Around the World." Annual Review of Political Science 16: 73-99. 
Gottlieb, Jessica. 2021. "Keeping the State Weak to Prevent Programmatic Claim-Making in Young Democracies." Unpublished manuscript .

Goyal, Tanushree. 2019. "Do Citizens Enforce Accountability for Public Goods Provision? Evidence from India's Rural Roads Program." Unpublished manuscript .

Grossman, Guy, and Kristin Michelitch. 2018. "Information Dissemination, Competitive Pressure, and Politician Performance between Elections: A Field Experiment In Uganda." American Political Science Review 112 (2): 280-301.

Grossman, Guy, Kristin Michelitch, and Carlo Prato. 2021. "The Effect of Sustained Transparency on Electoral Accountability." Unpublished manuscript .

Grossman, Guy, Kristin Michelitch, and Marta Santamaria. 2017. “Texting complaints to politicians: Name personalization and politicians' encouragement in citizen mobilization." Comparative Political Studies 50 (10): 1325-1357.

Grossman, Guy, Macartan Humphreys, and Gabriella Sacramone-Lutz. 2014. ““'I wld like u WMP to extend electricity 2 our village": On Information Technology and Interest Articulation." American Political Science Review 108 (3): 688-705.

Grossman, Guy, Macartan Humphreys, and Gabriella Sacramone-Lutz. 2020. "Information Technology and Political Engagement: Mixed Evidence from Uganda." Journla of Politics 82 (4): 1321-1336.

Grossman, Guy, Melina Platas, and Jonathan Rodden. 2018. "Crowdsourcing accountability: ICT for service delivery." World Development 112: 74-87.

Grossman, Guy, and W Walker Hanlon. 2014. "Do Better Monitoring Institutions Increase Leadership Quality in Community Organizations? Evidence from Uganda." American Journal of Political Science 58 (3): 669-686.

Gulzar, Saad. 2021. "Who Enters Politics and Why?" Annual Review of Political Science 24: 253-275.

Gulzar, Saad, and Benjamin J. Pasquale. 2017. "Politicians, Bureaucrats, and Development: Evidence from India." American Political Science Review 111 (1): 162?183.

Hanna, Rema, and Shing-Yi Wang. 2017. "Dishonesty and Selection into Public Service: Evidence from India.” American Economic Journal: Economic Policy 9 (3).

Harding, Robin. 2015. "Attribution and Accountability: Voting for Roads in Ghana." World Politics 67: 656-689.

Hicken, Alan, and Noah Nathan. 2020. “Clientelism's Red Herrings: Dead Ends and New Directions in the Study of Nonprogrammatic Politics." Annual Review of Political Science 23: 277-294.

Huber, John D., and Michael M. Ting. 2021. "Civil Service and Patronage in Bureaucracies." Journal of Politics 83 (3): in print. 
Incerti, Trevor. 2020. "Corruption Information and Vote Share: A Meta-Analysis and Lessons for Experimental Design.” American Political Science Review 114 (3): 761-774.

Kaawa-Mafigiri, David, and Eddy Joshua Walakira. 2017. Child abuse and neglect in Uganda. Springer.

Khan, Adnan Q, Asim Ijaz Khwaja, and Benjamin A Olken. 2019. "Making Moves Matter: Experimental Evidence on Incentivizing Bureaucrats through Performance-Based Postings." American Economic Review 109: 237-70.

Kosack, Stephen, and Archon Fung. 2014. “Does Transparency Improve Governance?” Annual Review of Political Science 17: 65-87.

Kruks-Wisner, Gabrielle. 2018. Claiming the State: Active Citizenship and Social Welfare. New York, NY: Cambridge University Press.

Larreguy, Horacio, John Marshall, and James M Snyder. 2020. "Malfeasance: When the Local Media Structure Facilitates Electoral Accountability in Mexico.” The Economic Journal 130 (631): 2291-2327.

Larreguy, Horacio, John Marshall, and James M. Snyder Jr. 2020. "Publicizing Malfeasance: When the Local Media Structure Facilitates Electoral Accountability in Mexico." The Economic Journal 130 (631): 2291-2327.

Leaver, Clare, Owen Ozier, Pieter Serneels, and Andrew Zeitlin. 2021. "Recruitment, effort, and retention effects of performance contracts for civil servants: Experimental evidence from Rwandan primary schools." American Economic Review (forthcoming).

Li, Christopher M., Greg Sasso, and Ian Turner. 2019. "Accountability in Governing Hierarchies.” Unpublished manuscript.

Lieberman, Evan S, Daniel N. Posner, and Lily L. Tsai. 2014. "Does Information Lead to More Active Citizenship? Evidence from an Education Intervention in Rural Kenya." World Development 60: 69-83.

Lieberman, Evan, and Yang-Yang Zhou. 2021. "Self-efficacy and Citizen Engagement in Development: Experimental Evidence from Tanzania." Journal of Experimental Political Science (forthcoming).

Lipsky, Michael. 1980. Street-Level Bureaucracy: Dilemmas of the Individual in Public Services. New York, NY: Russell Sage Foundation.

Loyalka, Prashant, Sean Sylvia, Chengfang Liu, James Chu, and Yaojiang Shi. 2019. "Pay by design: Teacher performance pay design and the distribution of student achievement." Journal of Labor Economics 37 (3): 621-662.

Manin, Bernard, Adam Przeworski, and Susan C. Stokes. 1999. "Introduction.” In Democracy, Accountability, and Representation, ed. Bernard Manin, Adam Przeworski, and Susan C. Stokes. Cambridge University Press pp. 1-26. 
Mansuri, Ghazala, and Vijayendra Rao. 2012. Localizing development: Does participation work? Wasington DC: The World Bank.

Martin, Lucy, and Pia Raffler. 2021. "Fault Lines: The Effects of Bureaucratic Power on Electoral Accountability." American Journal of Political Science First View.

McAndrews, John R., Jonah I. Goldberg, Peter John Loewen, Daniel Rubenson, and Benjamin Allen Stevens. 2020. "Non-Electoral Motivations to Represent Marginalized Groups in a Democracy: Evidence from an Unelected Legislature." Legislative Studies Quarterly . (forthcoming).

McClendon, Gwyneth H. 2016. "Race and Responsiveness: An Experiment with South African Politicians." Journal of Experimental Political Science 3 (1): 60-74.

Ofosu, George Kwaku. 2019. "Do Fairer Elections Increase the Responsiveness of Politicians?" American Political Science Review 113 (4): 963 ?979.

Olken, Benjamin A. 2007. "Monitoring Corruption: Evidence from a Field Experiment in Indonesia." Journal of Political Economy 115 (2): 200-249.

Paller, Jeffrey W. 2019. "Dignified Public Expression: A New Logic of Political Accountability." Comparative Politics 52 (1): 85-116.

Peisakhin, Leonid, and Arturas Rozenas. 2018. "Electoral effects of biased media: Russian television in Ukraine." American journal of political science 62 (3): 535-550.

Pepinsky, Thomas B., Jan H. Pierskalla, and Audrey Sacks. 2017. "Bureaucracy and Service Delivery." Annual Review of Political Science 20 (1): 249-268.

Pierskalla, Jan H, and Audrey Sacks. 2020. "Personnel Politics: Elections, Clientelistic Competition and Teacher Hiring in Indonesia.” British Journal of Political Science 50 (4): 1283-1305.

Platas, Melina Raquel, and Pia J Raffler. 2021. "Closing the Gap: Information and Mass Support in a Dominant Party Regime." Journal of Politics (forthcoming).

Posner, Daniel N. 2005. Institutions and ethnic politics in Africa. Cambridge University Press.

Raffler, Pia. 2020. "Does Political Oversight of the Bureaucracy Increase Accountability? Field Experimental Evidence from a Dominant Party Regime.” Unpublished manuscript.

Raffler, Pia, Daniel N. Posner, and Doug Parkerson. 2020. "Can Citizen Pressure be Induced to Improve Public Service Provision?” Unpublished manuscript.

Rasul, Imran, and Daniel Rogger. 2008. "Management of Bureaucrats and Public Service Delivery: Evidence from the Nigerian Civil Service." The Economic Journal 128 (608): 413-446.

Rozenas, Arturas. 2016. “Office insecurity and electoral manipulation.” The Journal of Politics 78 (1): 232-248. 
Rueda, Miguel R, and Nelson A Ruiz. 2020. "Political agency, election quality, and corruption." The Journal of Politics 82 (4): 1256-1270.

Ruiz, Nelson A. 2020. "The Power of Money. The Consequences of Electing a Donor Funded Politician." Unpublished manuscript .

Slough, Tara. 2020a. "Bureaucratic Quality and the Observability of Electoral Accountability." Unpublished manuscript.

Slough, Tara. 2020b. "Bureaucrats Driving Inequality in Access: Experimental Evidence from Colombia." Unpublished manuscript.

Slough, Tara. 2020c. "Oversight, Inequality, and Capacity.” Working paper, New York University.

Spenkuch, Jorg L, Edoardo Teso, and Guo Xu. 2021. Ideology and Performance in Public Organizations. Technical report National Bureau of Economic Research.

Ting, Michael M. 2021. "The Political Economy of Governance Quality." American Political Science Review 115 (2): 667-685.

Toral, Guillermo. 2019. "The Benefits of Patronage: How the Political Appointment of Bureaucrats Can Enhance Their Accountability and Effectiveness." Unpublished manuscript.

Toral, Guillermo. 2020. “Turnover: How Electoral Accountability Disrupts the Bureaucracy and Service Delivery.” Unpublished manuscript.

Tsai, Lily L. 2007. "Solidarity Groups, Informal Accountability, and Local Public Goods Provision.” American Political Science Review 101 (2): 355-372.

Ujhelyi, Gergely. 2014. "Civil Service Rules and Policy Choices: Evidence from US State Governments." American Economic Journal: Economic Policy 6 (2): 338-380.

Wängnerud, Lena. 2009. "Women in Parliaments: Descriptive and Substantive Representation." Annual Review of Political Science 12: 51-69.

White, Ariel, Noah L. Nathan, and Julie K. Faller. 2014. "What Do I Need to Vote? Bureaucratic Discretion and Discrimination by Local Election Officials." American Political Science Review 109 (1): 129-142.

World Bank. 2003. World development report 2004: making services work for poor people. The World Bank.

$\mathrm{Xu}$, Guo. 2021. "Bureaucratic Representation and State Responsiveness: The 1918 Pandemic in India." Review of Economics and Statistic (forthcoming).

$\mathrm{Xu}$, Guo, Marianne Bertrand, and Robin Burgess. 2020. "Organization of the State: Home Assignment and Bureaucrat Performance." Unpublished manuscript .

Yazaki, Yukihiro. 2018. "The Effects of Bureaucracy on Political Accountability and Electoral Selection.” European Journal of Political Economy 51: 57-68. 
York, Erin. 2020. "Votes for Effort: Electoral Accountability under Autocracy.” Unpublished manuscript. 